\title{
Varosha and Kyrenia: Where is Environmental Ethics?
}

\author{
Ayşe Şat \\ Girne American University
}

\begin{abstract}
At the beginning of the 20th century, the technological developments influenced the harmony between nature and people that appeared in ancient times. Thus, the harmony between nature and people started to destroy. Because of these changes, people started to gain control over nature and use it for their own needs. Then, people started to face with the environmental problems, such as increasing the use of petroleum and petroleum products, fast production of chemical drugs and new model cars, and the using of new communication technologies. In addition, other environmental problems can be shown as the increasing of population and the atomic waste. That is why the natural sources: air, water, and earth, which are the reason of our lives, are polluted by people. So, what are the environmental problems? And how can we save our environment? Hence, this short paper will use Varosha and Girne (Kyrenia) as an example to discuss the concept of environmental ethics and the environmental problems. Also the paper will be instantiated by the visual and verbal texts, such as photos and written signs. In short, the main aim of the paper is to create awareness, show the environmental problems at North Cyprus, think about these problems, and at the end try to find the solutions. And even this paper will suggest that technology and science are not enough to solve the problems. That is why, with the technological and scientific developments, we need new discourses to educate society, academicians, teachers, and specially children and youth through philosophy and media. Consequently, Çücen (2011) mentions Bookchins' ideas that only people have extraordinary consciousness to create ethical system and judge others. Thus, the paper will work on Environmental Ethics and Environmental problems in North Cyprus (KapalıMaraş/Varosha and Girne/Kyrenia) in four parts. The first part will talk about philosophy and nature; the second and third parts define the meanings of Ethic and Environmental Ethics; and the last part of the paper will talk about the environmental problems of Varosha and Kyrenia and finish the paper with suggestions.
\end{abstract}

Keywords: philosophy, environmental problems, environmental ethics, Varosha and Kyrenia.

The harmony between nature and human at the early ages has started to be destroyed with the fast improvements of technology at the beginning of 20th century. The increase in the use of petroleum and its derivations, the increase in the production of chemicals which is directly proportionate with the fast improvements of the technology, fast production of new model cars, and the use of new technological communication systems establish only a few of the environmental problems. In addition to those, the considerable increase in the human population and nuclear waste can be shown as causes. As a result, the natural sources that constitutes the reason to live-air, water, and soil-are being polluted by us as time goes by. Then what are the environmental issues that are also the reason we live and how can we protect our

Ayşe Şat, Senior Lecturer , English Language and Literature Humanities Faculty, Girne American University, North Cyprus; main research fields: World Literature, Literary Theories, Psychology, Philosophy, and Space Theories. Email: ayse_lit@hotmail. com. 
environment? Intrinsically, protecting the environment also means protecting humankind. This short article where we may find answers to such questions will discuss environmental problems which are also the environment ethics in four sections. In the first section philosophy and nature, in the second section ethics, and the third one the environment ethics will be mentioned and in the last section Kyrenia and Varosha in the North part of the island of Cyprus will be exemplified by referring the concerns in these areas and then the article will be concluded.

It is necessary to identify or define the problems in order to find answers to the questions above. Although, the environmental issues regarding Kyrenia and Varosha are numerous, this article will only study the pollution of historical attractions, pollution of shores, and the pollution of common areas. At the end of this study, in prior to mentioning what must be done in order to protect the nature, it is essential to define the concepts of nature, ethics, and environmental ethics.

\section{Philosophy and Nature}

I am in favour of the opinion that mere science and technology would not be sufficient to overcome environmental issues. Along with these, it is necessary to educate society, especially teachers, academics, and most importantly young people and children with new expressions. So we need to educate the society by using philosophy, philosophical movements, media as well as science and technology. With this point of view, it would be appropriate to mention the ancient nature philosophy that makes nature and human closer to each other. Thales, one of the Ionian philosophers in B.C. 600 had started the first philosophy of nature with the expression "Water is the main substance of everything" (Çüçen 2011, 1). In addition to the philosophy of Thales, other ancient philosophers such as Anaksimandros, Herakleitos, Anaksimandros, and Demokritosi (Cevizci 2010, 37-62) had combined nature with human and linked our reason to live to nature:

Afterwards, human philosophy had humankind ahead of nature with the broader meaning of knowledge/mind:

Socrates positions human in the centre of philosophy by opposing nature philosophy and grounding on the human life. Human philosophy within B.C. 500 and 400 starts with the questions Socrates asked young people about humankind in the streets of Athens. This philosophy that continued with Socrates's student Plato and Plato's student Aristotle has changed in definition and stopped being a thinking process in search of a main substance. Human accept an understanding of philosophy that asks questions about the society they live in and its government during the ages of these three philosophers. During the Hellenistic Period, Epicurus regenerates and improves the atomic mechanist point of view of Democritus. Also, Stoics regenerates and improves the Heraclitus' dynamic understanding of nature. However, Neo Platonists, claims entirely abstract thoughts in this field. In the Middle Ages, the scientific analysis of nature has been largely neglected. The philosophy of this period is a combination of Aristotelianism, Platonism, and Christian metaphysics. Philosophers in the Middle Age who handle philosophy in regards to theology had considered philosophy as a tool for divinity. Philosophy works with theology for the existence and knowledge of God which is the main thing ever. The only thing about philosophy is God. Within a God centred philosophy approach, belief, divine inspiration, and intuition are the information types that reflect reality. Mind is vicarious information that explains nature formations. (Çüçen 2011, 2)

Human philosophy that recedes from nature within the Middle Age period have started to dominate nature in Modern Period.

During modern philosophy period, human and nature have fallen into a contradiction. For instance, Bacon, a Renaissance period philosopher, has expressed the relation between nature and human, which is also quoted in Çüçen's article: 
Humankind, the servant of nature can do an act and obtain information within measures of his understanding the secrets of the order of nature via experiment and thinking. The condition of dominating the nature is to overpower it. The ambition of "overpowering nature" which was started with Bacon has turned into an ambition of exploiting the nature with the industrial revolution. This ambition had embittered the consumption economy. With consumption, both nature and humankind itself has reached to the point of consumption. Along with Modern Era, the mind has started opposing things which were not creations of itself by unfurling a flag and entered in to the process of auditing and making things dependent on itself. Philosophy has become a rational thinking system that makes explanations on human-centred information, entity, and ethics. (Çüçen 2011, 2)

After Bacon, Descartes, the leader of modern philosophy, had started the mind and body contradiction and gave priority to knowledge by attaching importance to the mind instead of body which is the soul:

The body, as a part of the physical world, is in the study field of nature science. However, the soul is outside the physical world. Descartes geometrized the substance by degrading it to size, shape, and movement. He even used to comprehend the existence of materialistic things by considering them as geometric evidences because he could only understand those when they were clear and distinct. He explained substance with the dynamism of its parts and so Descartes used to design substance as a "machine". So the knowledge of modern philosophy is the knowledge of mathematical physics. This knowledge is objective and reflects what is in the nature as it is. It is quantitative and testable by everyone. The approach of new epistemology is individualist, analyst, and minimalist. The mechanic perception is rational, scientific, and techno-centered. (Çüçen 2011, 2)

Therefore the harmony between nature and human during first ages has destroyed and human beings had started to use nature for their own benefits instead of helping it to survive. In accordance with this, today's nature philosophy has been divided into two as Çücen's had also mentioned:

Today the concept of nature philosophy is formed in regard to the main directions and dimensions of nature as a reality within the general and hypothetical scope and divides into two as physical and biological philosophy. Proceeding with this discipline where the main and the most important aspects of natural reality is considered, the reality itself as a whole, the nature philosophy is very important discipline not only from a philosophical view but also in a practical way, because of the reasoning regarding the world perception of human anthropology and ethics. In other words, nature philosophy which is a type formed by investigations regarding actual dimensions of nature as a reality is established by philosophy of physics and biology. In this context, the philosophy of nature works to reason out from investigations regarding nature with the understanding of conditioning the beliefs and attitudes with a strong comprehension towards the natural formation of humankind. (Çüçen 2011, 3)

The matter Çüçen has mentioned here is about human starting to investigate the nature practically in the technological era. Because the humankind started to understand that the nature is gradually being destroyed and created the environmental ethics. However, it would be more appropriate to define the concept of ethics prior to defining the environmental ethics.

\section{Ethics}

"Ethics is a relative concept" (Bodur 2006, 1) and is being regenerated and renewed in accordance with time and place. When we think about the technological century we live in, ethics is keeping up with the developing science and technology and starting to have new meanings. However, before we probe the concept of ethics in today's meaning, we need to take a look at the root of ethics concept and knowing how the concept of ethics was defined in the past would be useful for us to understand the concept of ethics in today's world:

The word of ethics originates from the word of "ethos" in Greek language and can be used in two different ways with the first meaning in Greek which is written as $\varepsilon \theta 0 \varsigma$, meaning habits, manners, and customs. The person trying to organize his 
acts according to valid manners via education behaves in the ethics as long as it follows the norms of "code of ethics" which is widely accepted. However in the strict and main sense, the person who acts and behaves according to the ethics written as $\eta \theta 0 \varsigma$ carries out the transmitted action rules and virtues without questioning but turns it into an habit in order to realize the requested good by comprehending and thinking about it. In this way ethics gains the meaning of character and become meaningful as the main attitude of being virtuous (Peiper 1999, 30). In daily life language, the word of ethics is sometimes used to emphasize the manners/moral and sometimes the character/morality. (Uzun 2007, 11)

Needless to say that as time goes by, the concept of ethics has been redefined just as the changing world, regime, and people and new ideas have been thrown out for consideration. For instance, as it was mentioned in the book named The Problems of Communication Ethics, Problems, and Responsibilities by RuhdanUzun:

The main purpose of ethics "is to show that the person is responsible to make properly based moral decisions on his own and should not give into anybody - neither to any authority or so called a more competent people (mother, father, teacher, religious functionary, etc.)" (Pieper 1999, 21). In other words, ethics would illustrate ways to make people realize oneself as himself while living with others in a society or exist as he is instead of letting someone ward him. Therefore ethics is human-centred; it is interested in organizing and leading the relations between human beings. Today, even if the concepts such as environmental ethics can be mentioned, it is because the destructions in the global eco-system have become a threaten to the humankind and next generations and this is also originated from humankind. (Uzun 2007, 11)

Correlated with human, the concept of ethics is largely necessary in this technological era and is helpful to overcome problems, especially the environmental issues.

\section{Environmental Ethics}

Nature and humankind have lived in harmony for centuries, with the development of science and rationale, "with the idea that the environment is in danger, the philosophical investigation on the relationship between nature and humankind is called environmental ethics" (Çüçen 2011, 3). As is cited above, nature was considered as the initial material of constitution during the first age philosophy:

The understanding of positioning the nature against humankind starts with Bacon and Descartes considering the mind as the sole power. Today human guided by the mind does not wander around as a master of a mystical or religious world in nature but a computable and expressible mechanic one. The opportunities offered generously by the nature have become the test site of scientific improvements and technology. This case leads the environmental moralist to minimize their bonds with technology. Because the overall tendency is to break free from the destructive effect of technology. Ecological point of views gives importance to the emotional bond between humankind and nature and institutional knowledge rather than hypothetical knowledge where everything is designed by "the mind" which has been given a start by Bacon and Descartes. (Çüçen 2011, 4)

When the people realized the power of nature, they started to use the environment in accordance with their own interests. In other words "in general meaning the environmental ethics is the systematically analysis of ethical relations between human and their natural environments. Environmental ethics assumes that moral rules manage and should manage the behaviours of human in front of the natural world" (Keleş 2006, 46). As a result of this, the environmental movements have appeared.

The starting process of ecologist movements should be considered as a three-way approach: the first way is the scientific environmentalism movement. The most important name of this period is Ernst Heackle. Heackle, a biologist, has established the science of ecology in 1876. With the science of ecology, it is important to have a natural balance and a protection of the natural things which are the extensions of this balance and this started to take important role in the agenda of humankind. The second way is the ecologist movement 
appearing as a social one with the incidents in 1968. The last one is an ecologist movement which started in 1979, turned into a formation of politics, and also started the greens movements (Çüçen 2011, 3).

The aim is to affect the societies, raise awareness, and put the nature under protection to some extent for future generations. Çüçen has separated the main movements of environmental philosophy as Deep Ecology, Social/Communal Ecology, and Ecofeminism.

The main movement this article will mention is social or in other words the communal ecology. It would not be a wrong argument to support the idea that $90 \%$ of environmental issues are caused by community. Because, the progression of technology has caused the increase in population and wars that are human-centred concerns and are held responsible for the environmental degradation. Then, how can the Social/Communal Ecology be defined?

It asserts that the assumption on the necessity of human ruling over and exploiting the nature result from human ruling over and exploiting human. So if approached reversely; in oppose to the assumption that "human will dissolve nature with labour and become free", the idea that human can only become free by enriching nature with a harmonious ethical and ecological action is supported. Almost all of today's ecological issues arise from rather well ingrained social problems and according to Bookchin, the founder of social ecology, the distinction of human and nature, the hierarchical perception of nature, and the effort of dominating over nature have appeared in societies where hierarchical relationship types are established. It does not matter how hard we try, nature and relations would not get in harmony with rituals, magic words, eco-theologies, and assimilation of "natural" life styles unless these hierarchical relations are ruled out. According to him, the ecological movements are communal movements and the environmental issues are social issues. (Çüçen 2011, 8)

For example, the environmental concerns we encounter in the areas of Kyrenia and Varosha are perceived as social/communal concerns. It would be more appropriate to speak of the environmental issues in general before analyzing the environmental issues in these areas. Section 8 Environment and Community in the Geography book for 11th grade students in Turkey illustrates environmental problems in the diagram below.

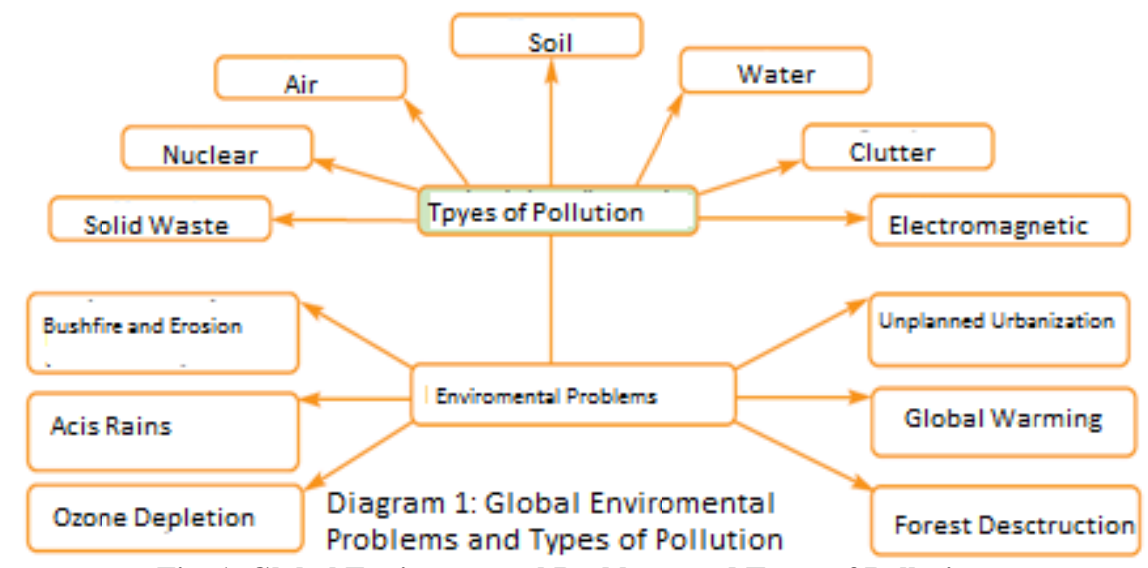

Fig. 1. Global Environmental Problems and Types of Pollution.

As can be seen in the diagram, the environmental problems and types of pollution are more than we approximate. Therefore the last two sections will mention the environmental issues in Kyrenia and Varosha.

\section{The Environmental Problems in Kyrenia and Varosha}

This last section will focus on the ecological concerns in Kyrenia and Varosha. While these problems are being transmitted, they will also be analysed by using visual images. As it was mentioned earlier, along with the environmental issues, the Turkish Cypriot people is growing lazy and getting selfish with the advances in 
science and technology and the population is increasing correlatively, the use of biological and chemical substances, weapons, and such numerous substances is increasing. Therefore this section is divided into two separate parts. In the first part, Varosha and in the second, Kyrenia issues will be mentioned.

Varosha in Famagusta district is also called Maras, Varosia or "B $\alpha \rho \omega ́ \sigma \iota \alpha$ " (Wikipedia) was once the most popular touristic and rich area of Cyprus. However, the area was invaded on 13th August, 1974 during the Second Operations + of Cyprus by Turkish Armed Forces. After this agreement, the district became wire-wove and was closed for settlement. This wire-wove Ghost City is being inspected by Turkish Armed Forces and United Nations on the "Green Line" that divides the Island of Cyprus into two. One building owned by United Nations and six apartments owned by Turkish Armed Forces were assigned for the officers' club (Wikipedia). It is strictly forbidden to enter except the members of Turkish Armed Forces and the students in the district. The foreign tourists who want to visit the area cannot go further from Varosha Ayios Yuannis Church (Icon Museum) (Wikipedia). As being widely common, Varosha has been a global political issue. For this reason, the living things and structures (historical places) were left for death. As can be seen in the pictures at the end of the text, Varosha, with all plants, structures, all living things, and most importantly the past memories in the area, has been put behind iron wires because of political and economic reasons.

In other words, it becomes very difficult to talk about environmental ethics when politics is the issue. Because cleaning the environment means protecting and accessing it. However, the only way to clean Varosha is via government and military forces' help. But we as a society are only responsible for cleaning the areas we can reach. For example, cleaning Kyrenia and the districts around is not as hard as cleaning Varosha. Because we pollute Kyrenia and the districts around we are the ones to clean it. For this reason, the environmental issues in Kyrenia are not political but social/communal.

As The Golden Year in Tourism, headline on the page 28 of Haberdar newspaper dated 18th December, 2011, states, the city of Kyrenia is a rich city with its historical structure welcoming thousands of tourists and students every year. But we do not stop polluting Kyrenia which we always talk about and whose shores and fivefinger mountains we are proud of. As can be seen in the pictures as well, city of Kyrenia is being polluted by the wastes of what we eat and drink along with the cars, telephones, unplanned urbanization, and the increase in population and chemical wastes. Especially the cans and plastic bottles we call as solid wastes are the things we live with. As is known widely, these wastes do not dissolve in nature for years, but damage nature and pollute the water we drink.

Water is the substance that is affected fastest, easiest, and in the most severe way by the environmental pollution, because every kind of pollution can be cleaned by water. Because of the technological advances, factory wastes, waste oils, diesel oils, and tars from the sea vehicles, dangerous chemical substances from medical and paper factories, pesticides, fertilizers, and dish washing liquids get mixed in water and cause pollution. Water becomes an important source of disease as a result of biological pollution. Considering that there are phenol derivatives, lead, and ammoniac in water, let's see which diseases are caused: Phenol derivatives: failure in brain and circulatory system, renal failure, severe sore throat, vomiting, gastric bleeding, abdominal cramps, trauma, and respiratory arrest. Lead: disease in brain, kidneys, liver and stomach, digestive system, and bone marrow. Ammoniac: sicknesses such as irritations in throat, alimentary canal, digestive system, nausea, vomiting, and stomach aches (Geography Book, Chapter 8).

For example, as you will find in the pictures at the end of the text, sewage from some of the hotels in Kyrenia district and some of the premises in Kaskar area flows into the sea because of unplanned organization. 
Dirty water flowing into the sea penetrates in soil and then comes to our dinner tables and into our body.

In addition, as can be seen on the page 240 of the Geography book of 11th grade, plastic bottles, detergent bottles, cans, or perfume boxes which we consider as solid wastes disappear after a long term in nature:



Therefore, it is necessary to know that we need to throw our wastes into the bins and not to the environment and we need to teach this to our children. Certainly saving environment is not only limited with using bins or teaching our children. So in the last section, the precautions against environmental problems will be listed and the article will be concluded.

\section{Conclusion and Recommendations}

It is possible to frame the precautions in order to clean and protect the environment we pollute:

- Respect

- Education

- Recycling

- Media

- Awareness

As can be seen in the list above, the most important thing we need to do is to respect. When we start respecting ourselves and our environment, I believe we can minimize environmental pollution. Whatever the reason for environmental pollution is, we should protect the ecological environment in our hand and we should be aware that it does not belong only to us. If we act considering that there is a generation after us, our respect towards the natural environment we live in and people we live with will increase.

The other precaution is education. With education, we need to use media organs and non-governmental organizations in order to inform public, especially the young people and children. Because of the ideological wars during electoral periods, the printed and visual press talk about environmental issues and mention the precautions that should be taken. However, after the elections are completed, these problems are disregarded. For example, it is possible to list the environmental pollution-related news on different newspapers and in different time periods:

1. Authorities remain insensitive to the problem of daily farm in Karmi. Star Kıbrıs Newspaper.

2. The Association of Biologists Riotted-Shame On Such An Environment Year! Havadis Newspaper.

3. Natural Purification Being Put Into Practice. KKTChaber.com

4. Humiliating Scenes. Kibris Newspaper.

5. This Didn't Quite Suit Kyrenia. Kıbrıs Newspaper.

6. Municipality of Kyrenia is unable to cope with trash damps. Kibrıs Newspaper.

7. Can Varosha be reborn from its ashes? Radikal Newspaper.

8. Varosha is being cleaned. KKTChaber.com

Even though there is considerable pollution, there are only a few writings regarding the environmental problems on newspapers. For example, as is stated under the headline Civil Action for Turism on Havadis 
Newspaper dated 25th December, 2011, architect Gokhan Borhan calls for Baglikoy residents to rejuvenate Baglikoy. In addition to this report, the headline "Natural Purification being put into practice" on KKTChaber web site gave the good news that recycling finally started to be carried out in the Turkish Republic of Northern Cyprus.

As a result, I am in the opinion that with the help of printed and visual press and trainers, we will be able to overcome the environmental problems and create awareness on how to do this at least to some extent.

Because:

"Only human" says Bookchin, it is obvious that appraising other lives and having the capacity to create unique moral systems, they have special virtues for themselves. They are rare in biosphere as they are aware of their own behaviour and the ecological effect they create because no other type of life has this extraordinary consciousness endowed to itself by the evolution. Therefore we, the academics, trainers, and students should keep our environment clean and educate society, especially the young and children about the damages done to environment not being ethical with the help of social projects, speeches, philosophical knowledge, and media. (Çüçen 2011, 8)

\section{Work Cited}

Bodur, Feyyaz. "With the Examples of News and Photographs." The questioning of Ethic on Press, Global Communication Journal, No. 2. 2006. Retrieved 8 July, 2012. <http://globalmediajournaltr.yeditepe.edu.tr/hakemli\%20yazilar\%20pdf/06Fey yaz\%20BODUR.pdf>

Cevizci, Ahmet. History of Philosophy. İstanbul: Say Publishing, 2010.

Geography Book. 11th Grade Geography Book. Chap. 8: Environment and Society, Global Effects of Natural Resources, Türkiye. Retrieved July 10, 2012.<http://egitek.meb.gov.tr/aok/aok_kitaplar/AolKitaplar/Cografya_6/4.pdf>

Çüçen, Abdülkadir. “Deep Ecology.” Retrieved July 4, 2012. < http://dogaokulu.net/notlar/derinekoloji.pdf>

Keleş, Ruşen. Environmental Ethics. Trans. Joseph R. Des Jardins. İstanbul: İmgeBookstore, 2006.

Vikipedia. "Varosha, Kibris." Retrieved July 15, 2012. <http://tr.wikipedia.org/wiki/Mara\%C5\%9F,_K\%C4\%B1br\%C4\%B1s>

\section{Newspapers}

Authorities remains insensitive to the problem of daily farm in Karmi. Star Kıbrıs Newspaper. 17.11.2011, <http://www.starkibris. net/index.asp?haberID $=105718>$

The Association of Biologists Riotted—Shame On Such An Environment Year!, KibrisHaber.Com. 23.12.2011, <http://haberkibris. com/1fc0a829-2011_12_23.html>

Natural Purification Being Put Into Practice, HaberKKTC.com, 4.01.2012. <http://www.haberkktc.com/haber/dogal-aritma-proje leri-hayata-geciyor-22501.html>

Humiliating Scenes, Gündem Kibris Newspaper. 07.11.2011.<http://www.gundemkibris.com/utandiran-goruntuler-17263h.htm>

This Didn't Quite Suit Kyrenia, Kıbrıs Newspaper. 22.12.2011.<http://www.haberinyeri.net/girneye-yakismadi-123659h.htm>

Can Varosha be reborn from its ashes? Radikal Newspaper. 18.07.2011. $<$ http://www.radikal.com.tr/yasam/kapali_maras_kuller inden_dogar_mi-1056674>

Varosha is being cleaned, KKTChaber.com. 26.06.2011. $<$ http://www.haberkktc.com/haber/kapali-maras-temizleniyor-5403.html > As The Golden Year in Tourism Haberdar Newspaper. 18.12.2011, page 28.

Tourism Initiatives in Bağlıköy, Havadis Newspaper. 24.12.2011. <http://www.haberhavadis.com/ic-haberler/baglikoyde-turizm-a tagi.htm> 


\section{Appendix}

The Pictures of Varosha and Kyrenia
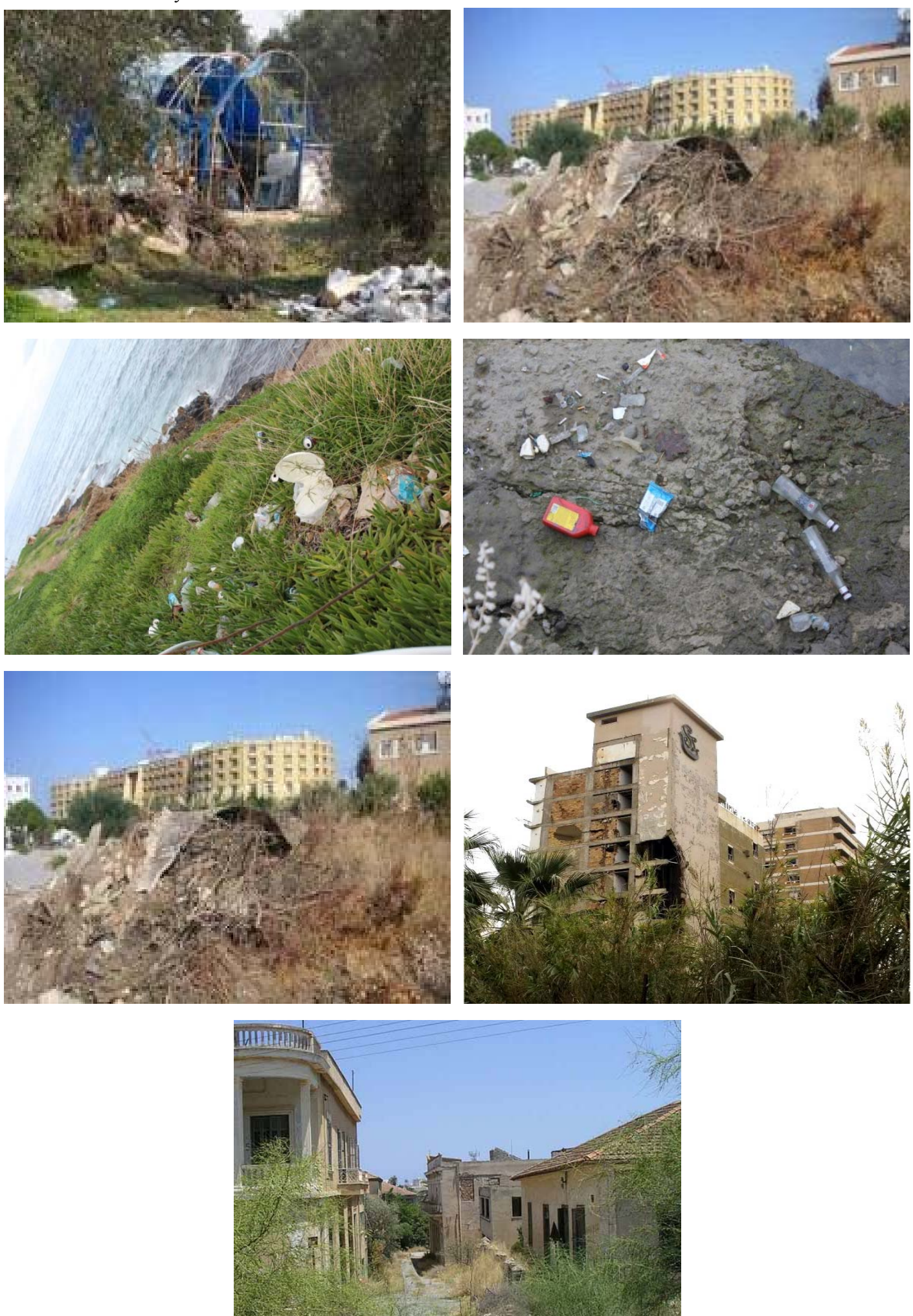